\title{
DIVERSIVIKASI USAHA DAN STRUKTUR MODAL
}

\author{
Wisudanto \\ Fakultas Ekonomi dan Bisnis Universitas Airlangga Departemen Managemen \\ e-mail: Wisudanto@feb.unair.ac.id

\section{Sugiarto} \\ Fakultas Ekonomi dan Bisnis Universitas Airlangga Departemen Managemen
}

\begin{abstract}
ABSTRAK
Keputusan strategi dalam beberapa literatur berpengaruh terhadap kinerja ekonomis perusahaan, salah satu keputusan strategi yang diambil perusahaan adalah diversifikasi.Diversifikasiyang konsisten dengan coinsurance effectdapat meningkatkan kapasitas utang, mengurangi resiko kebangkrutan, meningkatkan penyebaran aset, dan profitabilitas. Penelitian inibertujuan mengetahui pengaruh diversifikasi perusahaan terhadap struktur modal. Diversifikasi perusahaan diukur dengan menggunakan Jacquemin-Berry Entropy Index, sementara struktur modal diukur dengan long term debt to equity ratio.Penelitian ini dilakukan pada24perusahaan (bukan sektor keuangan) yang termasuk dalam daftar LQ45 yang melakukan diversifikasi. Hasil penelitian ini menunjukkan adanya pengaruh positif antara diversifikasi terhadap struktur modal perusahaan.Pengaruh diversifikasi terhadap struktur modal menguatkan pendapat bahwa keputusan strategi berpengaruh terhadap kinerja ekonomis kususnya kinerja keuangan perusahaan.
\end{abstract}

Kata kunci: Diversifikasi usaha, Coinsurance Effect, Struktur Modal. 


\section{Latar Belakang}

Bentuk usaha yang dikembangkan oleh konglomerasi di Indonesia berawal dari perusahaan keluarga, kemudian mereka berekspansi kedalam usaha sama sekaliberbeda dengan bisnis semula. Konglomerasi di Indonesia dilakukan dengan cara memperluas jumlah segmen secara bisnis maupun geografis, memperluas market share yang ada,dan mengembangkan berbagai produk yang beraneka ragam(Harto, 2005).

Meningkatkan kinerja bisnis yang ada dengan mengidentifikasi peluang dengan cara menambah unit bisnis yang tidak berkaitan dengan bisnis perusahaan saat ini disebut diversifikasi.Menendez-Alonso (2003)berpendapat bahwa diversifikasiyang konsisten dengan coinsurance effectdapat meningkatkan kapasitas utang, mengurangi resiko kebangkrutan, meningkatkan penyebaran aset, dan profitabilitas. Barton dan Gordon (1988)mengemukakan dalam penelitiannya bahwa diversifikasi produk berhubungan negatif dengan risiko dan berhubungan positif dengan tingkat utang,dengan menggunakan data perusahaan AS dan Australia. Penerapan diversifikasi, diharapkan jika salah satu segmen usaha mengalami kerugian, maka keuntungan yang diperoleh dari segmen usaha yang lain dapat menutupi kerugian tersebut.

Keputusan penting yang diambil oleh manajemen berkaitan dengan diversifikasi perusahaan adalah keputusan pendanaan yang digunakan untuk melakukan diversifikasi, hal ini akan berpengaruh terhadap struktur modal perusahaan.Myers (2003) berpendapat bahwa struktur modal mencerminkan imbangan antara utang jangka panjang dan ekuitas, maka didalam membelanjai aktiva yang ada perlu diperhatikan komposisinya dengan baik. Manajer harus mampu menghimpun dana baik yang bersumber dari dalam perusahaan maupun dari luar perusahaan secara efisien.Kochhar dan Hitt (1998)juga mengemukakan bahwa perusahaan melakukan diversifikasi memiliki rasio utang yang lebih tinggi karena pengurangan risiko. Singh et al. (2003)mengungkapkan perusahaan yang melakukan diversifikasi yang konsisten akan berpengaruh positif terhadap kemampuan hutang perusahaan, hasil ini konsisten dengan Coinsurance Effect.Xu dan Wang (1999)dengan menggunakan sample perusahaan di China dalam penelitiannya berpendapat bahwa jika diversifikasi dilakukan tidak terkait dengan bisnis utama berpengaruh positif terhadap kemampuan utang perusahaan.

Penelitian bertujuan untukmenganalisis apakah diversifikasi yang dilakukan perusahaan berpengaruh terhadap struktur modalperusahaan.Menggunakan sample 24 perusahaan tergabung dalam LQ45 di Bursa Efek Indonesia (BEI) selama periode 2009-2012yang melakukan diversifikasi,hasil penelitian ini diharapkan memberi informasi dalam proses pengambilan keputusan sehingga keputusan yang dihasilkan akan lebih tepat.

\section{Telaah Literatur dan Hipotesis}

Christensen dan Montgomery (1981) menjelaskan tiga pandangan alasan dilaksanakannya diversifikasi perusahaan, (1) Pandangan kekuatan pasar (market power view), yaitu diversifikasi merupakan alat untuk menumbuhkan pengaruh anti kompetisi yang bersumber pada konglomerasi. (2) Pandangan prespektif keagenan (agency view), terjadinya konflik kepentingan antara pemegang saham dengan manajer. Manajer kemungkinan bertindak tidak sesuai dengan kepentingan pemegang saham. Manajer mempunyai kecenderungan melakukan diversifikasi untuk memenuhi kepentingannya. Kinerja manajer sering kali dikaitkan dengan tingkat penjualan, sehingga diversifikasi merupakan alat yang efektif untuk meningkatkan pendapatan perusahan. (3) Pandangan yang mendasarkan pada sumber daya (resource based view) yang dimiliki perusahaan. Tujuan diversifikasi adalah untuk 
memanfaatkan kelebihan kapasitas dari sumber daya perusahaan. Tingkat optimal diversifikasi tiap perusahaan berbeda sesuai dengan sumber daya yang dimiliki perusahaan.

$\mathrm{Su}$ (2010)menggunakan Jacquemin-Berry entropy index, untuk mengukur optimalisasi diversifikasi(DIVR) digunakan rumus sebagai berikut:

$$
\begin{gathered}
\text { DIVR }=\sum_{k=1}^{n} P_{k} \ln \left(\frac{1}{p_{k}}\right) \\
k=1,2,3, \ldots \ldots, k n ; P_{k}: \text { Rasio dari penjualan per-segmen usaha dengan jumlah } \\
\quad \text { penjualan perusahaan. }
\end{gathered}
$$

\section{Coinsurance Effect}

Coinsurance effect menyatakan bahwa ketika perusahaan melakukan strategi penggabungan unit usaha yang berbeda bisnisnya dalam satu konglomerasi akan menurunkan resiko kebangkrutan perusahaan sebelumnya.Karena dua atau lebih perusahaan yang bergabung bersama dan mempunyai laba yang tidak berkorelasi akan mengurangi resiko kegagalan perusahaan gabungan, hal tersebut dapat meningkatkan kapasitas utang dari perusahaan konglomerasi (Lewellen, 1971). Diversifikasi memungkinkan perusahaan dengan arus kas kurang baik berkorelasi dengan segmen yang berbeda untuk mengurangi variabilitas laba sehingga kapasitas pinjaman perusahaan dapat mengalami peningkatan(Kim dan McConnell, 1977). Penelitian lain mengatakan bahwa dengan melakukan diversifikasi perusahaan dapat memperoleh pengurangan pajak dengan offsetting pembayaran bunga di beberapa segmen terhadap keuntungan segmen operasi yang lain (Berger dan Ofek, 1995).Coinsurance effectmuncul ketika perusahaan melakukan diversifikasi segmen usaha yang beragam sehingga perusahaan memiliki kapasitas utang yang lebih tinggi.Menendez-Alonso (2003)berpendapat bahwa diversifikasiyang konsisten dengan coinsurance effectdapat meningkatkan kapasitas utang, mengurangi resiko kebangkrutan, meningkatkan penyebaran aset, dan profitabilitas.

\section{Struktur Modal}

Van Horne dan Wachowicz (2008)berpendapat bahwa struktur modal adalah proporsi pendanaan permanen jangka panjang perusahaan yang terdiri dari hutang, saham preferen, dan saham biasa. Jadi struktur modal tersebut tercermin pada hutang jangka panjang dan unsur-unsur modal sendiri. Pemenuhan akan kebutuhan dana dapat diperoleh dengan baik secara internal perusahaan maupun secara eksternal. Bentuk pendanaan secara internal (internal financing) adalah laba ditahan, depresiasi, dan amortisasi. Pemenuhan kebutuhan yang dilakukan secara eksternal dapat dibedakan menjadi pembiayaan hutang (debt financing) dan pendanaan modal sendiri (equity financing).

Menurut Myers (1977) manajer akan berusaha menambah hutangnya hingga tingkat tertentu, dimana pengurangan hutang akibat tambahan hutang sama dengan atau benar-benar terimbangi oleh tambahan biaya kebangkrutan. Ini menjelaskan bahwa perusahaan yang memilki pajak tinggi cenderung menggunakan hutang dibandingkan dengan perusahaan yang memiliki pajak rendah. Tetapi penggunaan hutang yang terlalu tinggi dapat menyebabkan bahaya kebangkrutan dan biaya agensi yang tinggi. 
Penggunaan sumber-sumber pembiayaan perusahaan, baik yang merupakan sumber pembiayaan jangka pendek maupun sumber pembiayaan jangka panjang akan menimbulkan suatu efek yang biasa disebut dengan Leverage. Myers (2003) menjelaskan bahwa "Leverage didefinisikan sebagai penggunaan aktiva atau dana dimana untuk penggunaan tersebut perusahaan harus menutup biaya tetap atau membayar beban tetap". Dapat pula diartikan suatu kebijakan yang dilakukan oleh suatu perusahaan yang menginvestasikan dana atau memperoleh sumber dana yang disertai dengan adanya beban atau biaya tetap yang harus ditanggung perusahaan.

Jadi kebijakan leverage timbul jika perusahaan dalam membiayai kegiatan operasionalnya menggunakan dana pinjaman atau dana yang mempunyai beban tetap seperti beban bunga. Tujuan perusahaan mengambil kebijakan leverage yaitu dalam rangka meningkatkan dan memaksimalkan kekayaan dari pemilik perusahaan itu sendiri.Penggunaan leveragedalam penelitian ini antara lain penggunaan long term debt to equity ratio (LDER) adalahrasio yang digunakan untuk mengukur bagian dari modal sendiri yang dijadikan jaminan untuk hutang jangka panjang. Rumusnya adalah sebagai berikut :

Long Term Debt To Equity Ratio $=\frac{\text { Total Hutang Jangka panjang }}{\text { Total Ekwitas }}$

Berdasarkan rumusan masalah, tujuan penelitian, dan pembahasan telaah literatur yang dikemukakan diatas maka hipotesis dalam penelitian ini adalah sebagai berikut: (H1)Diversifikasi mempunyai pengaruh positif terhadap struktur modal.

\section{Kerangka Pemikiran}

Berdasarkan teori yang telah dipaparkan, kerangka pemikiran untuk memecahkan permasalahan penelitiansebagai berikut :

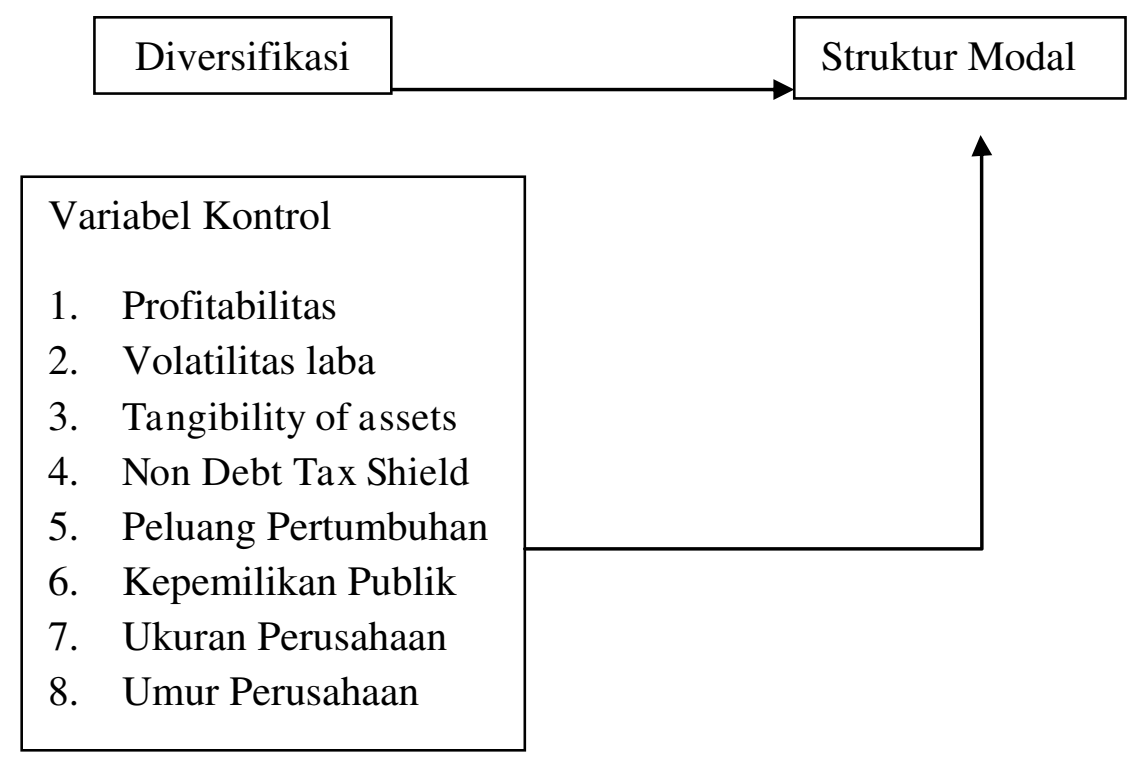

Gambar 2.1.

Kerangka pemikiran penelitian 


\section{Metode Penelitian}

\section{Identifikasi variabel}

Berdasarkan model analisis dan hipotesis penelitian, maka jenis variabel-variabel yang digunakan dalam penelitian ini adalah sebagai berikut:

1. Variabel bebas atau independen, yaitu variabel yang mempengaruhi atau menjadi sebuah perubahan variabel dependen (Sugiyono, 2009:59). Variabel bebas dari penelitian ini adalah diversifikasi perusahaan.

2. Variabel tergantung atau dependen, yaitu variabel yang dipengaruhi atau yang menjadi akibat dari adanya variabel bebas (Sugiyono, 2009:59). Variabel tergantung pada penelitian ini adalah struktur modal perusahaan dengan proksilong term debt to total equity ratio (LDER).

3. Variabel kontrol, merupakan variabel yang dikendalikan atau dibuat konstan hubungan variabel bebas terhadap variabel terikat sehingga variabel terikat tidak dipengaruhi oleh faktor luar yang tidak diteliti(Sugiyono, 2009:60).Variabel kontrol dalam penelitian ini antara lain profitabilitas, volatilitas laba, tangibility of asset, nondebt tax shield (NDTS), peluang pertumbuhan, kepemilikan publik, ukuran perusahaan, dan umur perusahaan.

\section{Definisi Operasional Variabel}

Untuk menghindari ketidakjelasan makna variabel yang digunakan dalam penelitian ini, maka definisi operasional variabel akan dijelaskan sebagai berikut:

\section{Leverage}

Leverage merupakan variabel terikat pada penelitian ini, yang di proksikan long term debt to total equity ratio (LDER) yang berfungsi mengukur seberapa besar ekuitas perusahaan yang digunakan untuk menjamin hutang jangka panjangnya. Data yang dipergunakan untuk analisis leverage adalah data laporan keuangan dari Indonesian Capital Market Directory (ICMD) dan annual report perusahaan.

$$
\text { Long Term Debt to Total Equity Ratio }{ }_{(i, t)}=\frac{\text { Long Term Debt }(i, t)}{\text { Total Equity }}
$$

\section{Diversifikasi}

Diversifikasi adalah variabel bebas yang mempengaruhi variabel terikat, diukur melalui penggunaan Jacquemin-Berry entropy index sesuai penelitian $\mathrm{Su}$ (2010). Penggunaan entropy index mengukur jumlah total diversifikasi (notasi DIVR) dari penjualan segmen usaha perusahaan yaitu dengan rumus sebagai berikut :

$$
\begin{array}{r}
\text { DIVR }=\sum_{k=1}^{n} P_{k(i, t)} \ln \left(\frac{1}{P_{k(i, t)}}\right) \\
\mathrm{k}=1,2,3 \ldots, \mathrm{kn}
\end{array}
$$


Wisudanto

Sugiarto
Jurnal Manajemen Bisnis Indonesia Vol. 2, Nomor 1, Oct 2014

DIVR $=$ Tingkat diversifikasi perusahaan i periode $\mathrm{t}$.

$P_{k(i, t)} \quad=$ Rasio dari penjualan per-segmen usahadengan

jumlah penjualan pada perusahaan i periode $t$

\section{Profitabilitas}

Hubungan antara profitabilitas dan struktur modal secara teoritis dan empiris masih kontroversial (Myers, 2003). Pecking ordertheory berpendapat struktur modal yang ceteris paribus, leverage akan mempunyai pengaruh negatif dengan profitabilitas karena perusahaan yang lebih menguntungkan akan lebih memilih memperoleh pembiayaan melalui dana internal daripada melalui utang.Namun, trade off dalam teori struktur modal memprediksi bahwa lebih banyak perusahaan yang menguntungkan memilih untuk menggunakan pembiayaan utang untuk mendapatkan keuntungan dari penghematan pajak. Maka, leverage akan mempunyai pengaruh positif dan negatif dengan profitabilitas. Ada bukti empiris yang mendukung kedua teori. Peneliti menggunakan pengembalian dari total aset (ROA) untuk mengukur profitabilitas dengan rumus sebagai berikut :

$$
\text { Return On Asset }{ }_{(i, t)}=\frac{\text { Nat Income }_{(i t)}}{\text { TotalAssets }_{(i, t)}}
$$

\section{Volatilitas laba}

Adanya ketidakpastian kestabilan lingkungan bisnis, maka kemungkinan kesulitan keuangan akan lebih besar pada setiap tingkat utang. Akibatnya, perusahaan dengan volatilitas pendapatan yang lebih tinggi akan memilih tingkat utang yang lebih rendah (Kale et al., 1991). Perhitungan didasarkan pada penelitian $\mathrm{Su}$ (2010) dan Kale et al. (1991) menggunakan koefisien variasi ROA dalam tiga tahun kebelakang sebagai proksi volatilitas pendapatan.

$$
\begin{aligned}
& \text { Rumus koefisien variasi dari } \mathrm{ROA}_{i, t}=\frac{S_{(i, t)}}{\bar{x}_{(i, t)}} \times 100 \% \\
& \text { Dimana : } \quad s_{i, t}^{2}=\frac{\sum_{i=1}^{n}\left(x_{i, t}-\bar{x}_{i, t}\right)^{2}}{n_{i, t}-1}
\end{aligned}
$$

$$
S_{i, t}=\sqrt{s_{i, t}^{2}}
$$

$$
\begin{array}{ll}
\text { Keterangan }_{(i, t)} & =\text { Simpangan baku perusahaan i periode } \mathrm{t} \\
s_{(i, t)}^{2} & =\text { Varian perusahaan i periode } \mathrm{t} \\
x_{(i, t)} & =\text { Data ROA tahun ke-i periode } \mathrm{t} \\
\bar{x}_{(i, t)} & =\text { Rata-rata ROA perusahaan i periode } \mathrm{t}
\end{array}
$$




\section{Tangibility of Assets}

Untuk mengurangi biaya agensi akibat moral hazard, kreditur umumnya memerlukan sebuah pinjaman perusahaan menggunakan aset berwujud sebagai jaminan. Oleh karena itu, LDER diprediksi mempunyai pengaruh positif dengan tangibility of asset (Su, 2010). Penelitian ini menggunakan rasio fixed assets dibagi total aset sebagai ukuran tangibility of asset (TANGIB). Metode menghitung aset berwujud adalah sebagai berikut :

$$
\text { Tangibility of } \text { assets }_{(i, t)}=\frac{\text { Fixed Assets (i,t) }}{\text { Total Assets } s_{(i, t)}}
$$

\section{Non-DebtTax shield (NDTS)}

Non-debt tax shield (NDTS), diukur dengan depresiasi dan amortisasi dibagi total aset. Depresiasi dan amortisasi adalah penentu struktur modal bukan dari hutang sebagai pendorong perusahaan untuk mengurangi hutang, karena depresiasi merupakan sumber modal internal sehingga diprediksi dapat mengurangi pedanaan hutang.NDTS mengurangi beban pajak perusahaan dengan demikian meringankan kebutuhan pembiayaan utang sebagai sarana untuk mendapatkan keuntungan pajak (Dammon dan Senbet, 1988). Dalam penelitian ini, menggunakan rumus sebagai berikut ;

$$
\operatorname{NDTS}_{(i, t)}=\frac{\text { Depresiasi }_{(i t)}+\text { Amortisasi }_{(i, t)}}{\text { Total Aset }}
$$

\section{Peluang pertumbuhan}

Perusahaan yang memiliki kemampuan tumbuh dan menguntungkan yang pada akhirnya akan mempengaruhi kinerja pada perusahaan. Pertumbuhan perusahaan memperlihatkan pertumbuhan penjualan perusahaan dan digunakan untuk memprediksi pertumbuhan perusahaan tiap tahunnya. Peneliti menggunakan Tobin's Q sebagai proksi peluang pertumbuhan (GROW), Chung dan Pruitt (1994)mengembangkan formulasi Tobin's Q seperti yang telah dijelaskan pada bab 2 persamaan (2.7) adalah sebagai berikut :

$$
\mathrm{Q}_{(i, t)}=\frac{M V E_{(i, t)}+D E B T_{(i, t)}}{T A_{(i t)}}
$$

Dimana:

$\mathrm{Q}_{(i, t)} \quad=$ Peluang pertumbuhanperusahaan ipada periode $\mathrm{t}$.

$\mathrm{MVE}_{(i, t)}=$ Nilai pasar ekuitas perusahaan ipada periode $\mathrm{t}$

(Jumlah saham perusahaan i yang beredar dikali dengan

harga penutupan saham akhir tahun pada periode t)

$\operatorname{DEBT}_{(i, t)}=$ Nilai buku dari total hutangperusahaan ipada periode $\mathrm{t}$.

$\mathrm{TA}_{(i, t)}=$ Nilai buku total aktiva perusahaan ipada periode $\mathrm{t}$. 


\section{Kepemilikan Publik}

Kepemilikan publik sering disebut sebagai pemegang saham minoritas (outsider investor) karena struktur kepemilikannya tersebar dan terdiri dari banyak saham yang dimiliki secara individu. Kepemilikan publik sering menimbulkan konflik kepentingan (agency conflict), karena outsider investors tidak memiliki informasi keadaan perusahaan yang sebenarnya dan hak kontrol terhadap perusahaan lemah. Sehingga manajer akan cenderung bebas dalam membuat keputusan pendanaan hutang ( $\mathrm{Su}, 2010)$. Oleh karena itu, penelitian ini memasukkan prosentase saham yang dimiliki oleh publik (Su, 2010), sebagai variabel kontrol dan memprediksi bahwa PUBLIC yang mempunyai pengaruh positif berkaitan dengan LDER.Metode menghitung prosentase kepemilikan publik:

$$
\text { PUBLIC }_{(i, t)}=\frac{\text { Kepemilikan Saham Oleh Publik }(i, t)}{\text { Total Saham Beredar }\left(i, t_{)}\right.} \times 100 \%
$$

\section{Ukuran perusahaan}

Perusahaan-perusahaan besar cenderung memiliki aset yang mumpuni, reputasi baik dan arus kas yang lebih stabil. Perusahaan besar lebih mungkin untuk melakukan diversifikasi, ukuran perusahaan berbanding terbalik dengan kemungkinan terjadi kebangkrutan Su (2010). Dengan demikian, perusahaan yang lebih besar diharapkan untuk membawa lebih banyak utang. Penelitian ini menggunakan logaritma natural dari total aset untuk mengendalikan efek ukuran perusahaan (LNSIZE). Metode pengukuran LNSIZE sesuai penelitian Su (2010) adalah:

$$
\text { Firm Size } e_{(i, t)}=\log \text { Total Assets } \text { (i, t) }_{\text {. }}
$$

\section{Umur Perusahaan}

Kemampuan perusahaan untuk meminjam tergantung pada akumulasi pengalaman dan reputasi. Perusahaan yang lama berdiri dan go public lebih mungkin untuk mendapatkan akses pendanaan dengan pemberi pinjaman, memperoleh utang lebih mudah, dan pada tingkat yang lebih murah, sehingga umur perusahaan (AGE) mempunyai pengaruh positifterhadap leverage perusahaan. Pengukuran AGE pada penelitian mengacu pada penelitianSu (2010) menggunakan jumlah tahun perusahaan telah go public untuk mengendalikan pengaruh umur (AGE).

\section{Sample Penelitian}

Sampel ditentukan dengan menggunakan metode purposive sampling,dengan ketentuan perusahaan sampel adalah perusahaan yang tergabung dalam LQ45di Bursa Efek Indonesia dari sektor non keuangan selama tahun 2009-2012. Perusahaan terdiversifikasi setidak nya dalam dua klasifikasi industri.

\section{Deskripsi Hasil Penelitian}

Agar dapat dilakukan analisis lebih jauh terkait permasalahan yang harus dipecahkan dalam penelitian ini deskripsi data dalam penelitain ini sebagai berikut. 
Tabel 1

Deskripsi Data Perusahaan Dalam Periode Penelitian (2009 - 2012)

\begin{tabular}{|l|l|l|l|l|l|}
\hline & $\mathrm{N}$ & Minimum & Maximum & Mean & $\begin{array}{l}\text { Std. } \\
\text { Deviation }\end{array}$ \\
\hline LDER & 24 & 0,033 & 1,352 & 0,421 & 0,371 \\
\hline DIVR & 24 & 0,014 & 1,597 & 0,596 & 0,401 \\
\hline STATE & 24 & 0,000 & 1,000 & 0,420 & 0,496 \\
\hline ROA & 24 & 0,011 & 0,452 & 0,123 & 0,101 \\
\hline STDROA & 24 & 0,018 & 1,133 & 0,269 & 0,232 \\
\hline NDTS & 24 & 0,008 & 0,923 & 0,241 & 0,222 \\
\hline TANGIB & 24 & 0,004 & 0,817 & 0,320 & 0,247 \\
\hline GROW & 24 & 0,650 & 15,003 & 2,642 & 2,626 \\
\hline PUBLIC & 24 & 0,074 & 0,835 & 0,379 & 0,161 \\
\hline LNSIZE & 24 & 29,211 & 34,086 & 31,160 & 1,268 \\
\hline AGE & 24 & 1,000 & 30,000 & 13,708 & 7,013 \\
\hline
\end{tabular}

Sumber : Data hasil olahan.

Hasil yang ditunjukkan pada table 1, kita dapat mengetahui bahwa nilai hitung Indeks Entropi paling rendah sebesar 0,014 yaitu pada PT. Tambang Batubara Bukit Asam (Persero) Tbk yang terjadi pada tahun 2011 sedangkan nilai hitung Indeks Entropi tertinggi terjadi pada PT.Lippo Karawaci Tbk. yaitu 1,597 pada tahun 2010. Nilai rata-rata yang dihasilkan indeks entropi dari tahun ke tahun mengalami peningkatan dan penurunan. Dimana nilai rata-rata keseluruhan sebesar 0,596, pada tahun 2009 nilai rata-rata yang dihasilkan sebesar 0,562 mengalami peningkatan menjadi 0,565 pada tahun 2010, lalu pada tahun 2011 nilai rata-rata meningkat sebesar 0,633, dan justru menurun lagi menjadi 0,626 pada tahun 2012 . Peningkatan nilai rata-rata indeks entropi dari tahun 2010 ke tahun 2011 pada periode penelitian, berarti penerapan strategi diversifikasi perusahaan mengalami peningkatan dan penerapan tingkat diversifikasi mengalami peningkatan pada tahun 2009 ke tahun 2011 dan kembali menurun pada tahun 2012. Nilai standart deviasi yang lebih kecil dari nilai rataratanya yaitu sebesar 0,401 menunjukkan bahwa terjadi perimbangan atau tidak ada ketimpangan persebaran tentang besar tingkat strategi diversifikasi dari tiap perusahaan yang menjadi objek penelitian.

Leverage pada penelitian ini diproksikan dengan utang jangka panjang (LDER) merupakan variabel terikat yang terdiri dari perbandingan antara jumlah utangjangka panjang dengan 
ekuitas perusahaan, itu dikarenakan perusahaan menggunakan utang pada struktur pendanaannya.Leverage yang besar merupakan cerminan penggunaan utang yang besar pula untuk struktur pendanaannya. Pada tabel 1 diketahui bahwa secara rata-rata LDER perusahaan sebesar 0,421 hal ini menyatakan bahwa rata-rata long term debtratio pada tingkatleverage selama tahun 2009 sampai dengan 2012 adalah sebesar 0,421dari total ekuitas yang dimiliki perusahaan sampel. Nilai minimum dari LDER terjadi pada PT. Astra Agro Lestari Tbk. tahun 2009sebesar 0,033 yang menunjukkan bahwa ekuitas yang digunakan untuk menjamin keseluruhan utang jangka panjangnya semakin besar.Nilai maksimum dari LDER terjadi pada PT. Indofood Sukses Makmur Tbk tahun 2009sebesar 1,352 yang menunjukkan bahwa ekuitas yang digunakan untuk menjamin keseluruhan utang jangka panjangnya semakin rendah.Nilai standart deviasi sebesar 0,371 yang lebih kecil dari nilai rata-rata menunjukkan bahwa terjadi perimbangan atau tidak ada ketimpangan tentang besar LDER yang dimiliki oleh masing-masing perusahaan sampel yang menjadi objek penelitian.

Hasil regresi yang dilakukan tampak pada Tabel 2, Koefisien variabel diversifikasi (DIVR) memberikan kontribusi positif sebesar 0,186 menunjukkan bahwa apabila variabel diversifikasi (DIVR), dalam hal ini nilai indeks entropi ditingkatkan sebesar 1 angka maka leverage (LDER) akan meningkat sebesar 0,186 dan sebaliknya, jika indeks entropi diturunkan sebesar 1 angka maka leverage (LDER) akan menurun sebesar 0,186 dengan asumsi variabel lain tetap. Diketahui hasil uji $\mathrm{t}$, dimana pengaruh variabel diversifikasi (DIVR) terhadap leverage (LDER) perusahaan memiliki nilai uji t sebesar 2,273 dengan tingkat signifikansi 0,026. Nilai signifikansi ini lebih kecil dari 0,05, sehingga dapat dinyatakan terdapat pengaruh positif signifikan secara parsial antara variable

Tabel 2

\section{Ringkasan Hasil Uji F dan Uji t Variabel Bebas}

Terhadap Variabel Tergantung Dengan Variabel Kontrol

\begin{tabular}{|l|l|l|l|l|}
\hline Variabel & $\begin{array}{l}\text { Koefisien } \\
\text { Regresi }\end{array}$ & Beta & $\mathrm{t}$ & Sig. \\
\hline (Constant) & 0,377 & & 0,443 & 0,659 \\
\hline Diversifikasi & 0,186 & 0,201 & 2,273 & 0,026 \\
\hline ROA & $-1,815$ & $-0,492$ & $-3,532$ & 0,001 \\
\hline Volatilitas Laba & 0,363 & 0,227 & 2,995 & 0,004 \\
\hline Tangibility of Assets & 1,016 & 0,677 & 5,719 & 0,000 \\
\hline Non-Debt Tax Shielded & $-0,375$ & $-0,224$ & $-1,850$ & 0,068 \\
\hline Peluang Pertumbuhan & 0,029 & 0,205 & 1,394 & 0,167 \\
\hline Kepemilikan Publik & 0,588 & 0,256 & 2,770 & 0,007 \\
\hline Ukuran Perusahaan & $-0,009$ & $-0,029$ & $-0,336$ & 0,738 \\
\cline { 2 - 5 } & & & &
\end{tabular}




\begin{tabular}{|c|c|c|c|c|}
\hline Umur Perusahaan & $-0,015$ & $-0,289$ & $-3,561$ & 0,001 \\
\hline $\mathrm{F}$ & 14,803 & & & \\
\hline Sig. & 0,000 & & & \\
\hline $\mathrm{R}$ & 0,780 & & & \\
\hline $\mathrm{R}^{2}$ & 0,608 & & & \\
\hline Durbin-Watson & 1,790 & & & \\
\hline
\end{tabular}

Sumber : data diolah

Berdasarkan data, hasil uji $\mathrm{F}$ pada tabel 4.9 diketahui bahwa nilai $\mathrm{F}$ hitung hasil regresi sebesar 14,803 dengan nilai probabilitas kesalahan (Sig) sebesar 0,000. Nilai signifikansi ini lebih kecil dari 0,05 sehingga terdapat pengaruh positif yang signifikan secara simultan antara variabel diversifikasi (DIVR) terhadap leverage perusahaan (LDER) dengan variabel kontrol Return On Assets (ROA), Coefficient Variation of Return on Assets (STDROA), Tangibility of Assets (TANGIB), Non-Debt Tax Shielded (NDTS), Growth Opportunities (GROW), PublicOwnership (PUBLIC), Firm Size (LNSIZE), Firm Age (AGE). Melalui tabel 4.9 dapat dilihat nilai $\mathrm{R}^{2}$ atau koefisien determinasi sebesar 0,608 , hal ini berarti bahwa diversifikasi berpengaruh terhadap leverage (LDER) perusahaan sebesar 0,608 atau 60,8\% sedangkan sisanya sebesar 0,392 atau 39,2\% dipengaruhi oleh variabel lain diluar variabel bebas yang digunakan dalam penelitian.

Secara khusus, manfaat menjaga leverage pada tingkat tertentu tidak hanya memberikan manfaat pada perspektif finansial saja tetapi juga manfaat pada perspektif strategis. Keputusan finansial dan keputusan strategis secara bersama-sama dipertimbangkan dan dikoordinasikan untuk memaksimalkan keuntungan.

\section{Simpulan dan Keterbatasan Penelitian}

Perusahaan LQ45 pada periode penelitian 2009-2012 menggunakan strategi diversifikasi dengan menggunakan banyak utang jangka panjang. Strategi ini berpengaruh terhadapstruktur modal perusahaan (LDER).Hasil penelitian menunjukkan bahwa variabel diversifikasi (DIVR) mempunyai pengaruh signifikan terhadap struktur modal (long term debt to equity ratio) perusahaan. Hasil ini konsisten dengan Coinsurance effectbahwa kombinasi usaha atau segmen usaha dengan arus kas yang berkorelasi tidak sempurna (dengan volatilitas tinggi) telah memberikan pengurangan risiko operasi, sehingga meningkatkan kapasitas utang perusahaan.

Pembahasan diversifikasi perusahaan hanya dibahas total diversifikasi perusahaan secara umum, belum melingkupi diversifikasi terkait dan tidak terkait hal ini menjadi keterbatasan dalam penelitian. 


\section{DAFTAR REFERENSI}

Barton, S. L., dan Gordon, P. J. 1988. Corporate strategy and capital structure. Strategic management journal, 9(6): 623-632.

Berger, P. G., dan Ofek, E. 1995. Diversification's effect on firm value. Journal of financial economics, 37(1): 39-65.

Christensen, H. K., dan Montgomery, C. A. 1981. Corporate economic performance: Diversification strategy versus market structure. Strategic management journal, 2(4): 327-343.

Chung, K. H., dan Pruitt, S. W. 1994. A simple approximation of Tobin's q. Financial management: $70-74$.

Dammon, R. M., dan Senbet, L. W. 1988. The effect of taxes and depreciation on corporate investment and financial leverage. The Journal of Finance, 43(2): 357-373.

Harto, P. 2005. KEBIJAKAN DIVERSIFIKASI PERUSAHAAN DAN PENGARUHNYA TERHADAP KINERJA: STUDI EMPIRIS PADA PERUSAHAAN PUBLIK DI INDONESIA. Jurnal Simposium Nasional Akuntansi: 1-11.

Kale, J. R., Noe, T. H., dan Ramirez, G. G. 1991. The effect of business risk on corporate capital structure: Theory and evidence. The Journal of Finance, 46(5): 1693-1715.

Kim, E. H., dan McConnell, J. J. 1977. CORPORATE MERGERS AND THE CO-INSURANCE OF CORPORATE DEBT. The Journal of Finance, 32(2): 349365.

Kochhar, R., dan Hitt, M. A. 1998. Linking corporate strategy to capital structure: diversification strategy, type and source of financing. Strategic management journal, 19(6): 601-610.

Lewellen, W. G. 1971. A pure financial rationale for the conglomerate merger. The Journal of Finance, 26(2): 521-537.

Menendez-Alonso, E. J. 2003. DOES DIVERSIFICATION STRATEGY MATTER IN EXPLAINING CAPITAL STRUCTURE? SOME EVIDENCE FROM SPAIN. Applied Financial Economics, 13(6): 427.

Myers, S. C. 1977. Determinants of corporate borrowing. Journal of financial economics, 5(2): 147-175.

Myers, S. C. 2003. Financing of corporations, Handbook of the Economics of Finance, Vol. 1: 215-253: Elsevier.

Singh, M., Davidson Iii, W. N., dan Suchard, J.-A. 2003. Corporate diversification strategies and capital structure. The Quarterly Review of Economics and Finance, 43(1): 147167.

$\mathrm{Su}$, L. D. 2010. Ownership structure, corporate diversification and capital structure: evidence from China's publicly listed firms. Management Decision, 48(2): 314-339. 
Van Horne, J. C., dan Wachowicz, J. M. 2008. Fundamentals of financial management: Pearson Education.

$\mathrm{Xu}, \mathrm{X}$. , dan Wang, Y. 1999. Ownership structure and corporate governance in Chinese stock companies. China economic review, 10(1): 75-98. 